\title{
Arrosoir, oui, Manhattan, non: Naming and the Law in France
}

\author{
Laurel Willingham-McLain
}

Carnegie Mellon University

The history of the French prénom 'given name' laws of 1803 and 1993 are recounted. The terms of the Consulate's 1803 law and how authorities have interpreted and applied them throughout the last two centuries are presented. The law was originally intended to prevent using last names as first names. However, in the twentieth century this same law was used to protect children from potentially harmful names. The naming law of 1993 appears to put into effect what had already become the practice. Sources of information include legal documents, interviews, newspapers and naming books for parents.

\section{Prologue}

It is a warm afternoon as Mr. Krafft, an Alsatian living in Paris, arrives at the town hall, tired but eager to fulfill the fatherly role of registering his newborn daughter, Saskia Marine Krafft. Saskia, the name of Rembrandt's wife, would remind his little girl of her Dutch ancestry on her mother's side, and Marine reminded him of the summer he met his wife-to-be at the seaside in Brittany. A poetic name, he thinks. He repeats it silently to himself as he walks into the town hall.

"And what are the baby's given names, sir?"

"Saskia Marine."

"You realize that you will have to put Marine first, and Saskia second on the birth certificate."

"No, we don't want to do that. It doesn't sound as good that way, and we intend to call her Saskia. It's a perfectly good name, a Dutch name."

"Well then, we need proof. Proof that it is a name used in the Netherlands. We can't fill out the forms until you provide us such proof."

Names 45.3 (September 1997):185-202

ISSN:0027-7738

() 1997 by The American Name Society 


\section{Names 45.3 (September 1997)}

Frustrated, angry, Mr. Krafft leaves the town hall to tell his wife, and to look for some proof that the name exists. The Kraffts don't have proof because they had not in the least expected this kind of difficulty. They had had no problem registering their first child, Vincent Arie, whose second name was Dutch. In any case, they are exhausted. Too exhausted to be creative.

What can they do? They have just three days to provide proof and declare the baby's birth. Mr. Krafft calls the town hall and finds out they will accept a document from the Dutch embassy, an entry from a name book, for example, with the embassy's official seal.

Off to the embassy he goes, but they have no such book of Dutch names. They recommend the municipal library.

Finally, after two days of running and waiting in lines, Mr. Krafft is able, though less willing this time, to register his daughter's birth. ${ }^{1}$

As I talked to people in Lille, France, and read about the law and naming, I found that this event had occurred in various forms over and over again. Nearly everyone I asked had a story to tell or an opinion to express about the French State and the choice of given names. My purpose here is to recount the development of the French prénom or 'given name' laws and to examine their twentieth century applications and interpretations.

Despite the legal priority generally given to family names, on April 1,1803 , la loi du 11 germinal an XI was adopted in order to guide the choice of first names. The Consulate found it necessary to do what the Catholic Church had done earlier through baptismal names; that is, to fix boundaries on the choice of given names. ${ }^{2}$ But the reasons of the Consulate were different. The law was passed in reaction to the excesses of the revolution and was designed primarily to forbid the bestowing of family names as given names (Lefebvre-Teillard 1990, 128).

Since it was clear that neither all the acceptable or unacceptable names could be listed, the law was written in the affirmative with an intended openness so that there would be few disputes, especially religious disputes. 
As stated in Article 1 of the 1803 law:

Les noms en usage dans les différents calendriers et ceux des personnages connus dans l'histoire ancienne pourront seuls être reçus comme prénoms sur les registres de l'état civil destinés à constater la naissance des enfants, et il est interdit aux officiers publics d'en admettre aucun autre dans leurs actes (Journal officiel 1990, 136).

"Only those names found on different calendars and those of people renowned in ancient history will be accepted as given names in état civil registers for recording the birth of children, and it is forbidden for public officers to admit any other name in certificates they draft." 3

Since the only previous practice the law really intended to forbid was the bestowal of family names as first names, it follows that Articles 2 and 3 made it possible, though not obligatory, for a person whose first name existed as a family name to change it through a simple judicial procedure. This permitted erasing the blot of one's parents overenthusiasm for the new Republic (Lefebvre-Teillard 1990, 128-30).

Very early in the twentieth century, two bills recommended almost complete liberty on the part of parents to choose their child's given names, with the only reservation being that the public officer make sure the child's best interests were served. A third bill provided adults with the possibility of changing their name when they felt it was ridiculous, cacophonous or socially harmful. None of the three bills, however, was ever brought before the legislature. Perhaps they were abandoned because they addressed too marginal a problem, or in contrast, because they were construed as a political project opposing the saints' names calendar at a time when tension over the relationship between the Church and the State was high (Lefebvre-Teillard 1990, 141-42).

Whatever the reason, the 1803 law, the only law governing the choice of first names, remained in effect until January 1993. Throughout the past two centuries, however, the interpretations and applications of this law evolved considerably. The 1966 and 1987 modifications of the Instruction générale relative à l'état civil specified how the law was to be applied (Journal officiel 1990, 136-139). They recommended that public officers be open-minded in interpreting the 1803 law, and that they proceed with registering children even if they that found one or all of the chosen names was unacceptable. 


\section{Names 45.3 (September 1997)}

This important revision was implemented after the famous case of the Le Goarnic family from Brittany, who named their children for Breton saints. Even though such names had been accepted in Brittany, they were refused in the Paris suburb where the family had moved. This refusal resulted in 19 years of administrative hassle during which the unregistered children did not exist in the State's eyes. As non-entities they could not receive family allowance, and they were exempt from school and military requirements. Though making future cases simpler, the revised General Instructions did not apply retroactively, and thus did not address the Le Goarnic problem, which was eventually resolved in international court (Adler 1978, 132-34; Besnard \& Desplanques 1991, 298; Rubellin-Devichi 1990, 138-39).

Given that the primary design of the 1803 law was to prohibit family names from being bestowed as given names, the original law was certainly not intended to exclude these Breton saints' names. How then was the law to be interpreted? Which calendars fit the vague description of "different calendars," and how was one to determine which names were considered renowned in "ancient history?" Why would such a law speak of names from ancient history as given names, when in many cultures the distinction between first and last names was a modern phenomenon? How were public officers to deal with foreign names, innovative feminized names, spelling variations, hyphenated names and multiple names? Though no provisions for these were included in the original text, most of these questions were addressed in the subsequent General Instructions (Journal officiel 1990, 136-39).

The General Instructions themselves stated that the law's primary goal was to prevent children from being given purely whimsical names. French children, of course, should normally be given French names, and thus "different calendars" were interpreted to mean French language calendars. An 1813 circular from the Ministry of the Interior had already clarified that "renowned in ancient history" referred exclusively to biblical tradition and Greco-Roman culture, generally excluding mythological figures (Journal officiel 1990, 136).

More recently, however, two principal criteria have been used for applying the law: a name must not be harmful (nuisible) to the child, and it must have an established usage in some tradition, somewhere. Whereas the General Instructions mentioned parents' desires only once, they invoked children's interests four times, and, contrary to Lefebvre- 
Teillard's reading of the original law $(1990,128)$, they stated that the law essentially served to spare children being called purely whimsical names (Journal officiel 1990, 136). The instructions admonished public officers to be open-minded, only refusing those names that could be harmful to children. It failed, however, to define what it meant by harm. Would ridicule qualify, or unrealistic expectations, or confusion? The only test provided to officials for approving a name was that it must be sufficiently sanctioned by use in some tradition.

The law divided names into three categories: "normally admissible," "conditionally admissible," and "inadmissible." Impossible as it was for the state to inventory all the possible admissible or inadmissible names, it was left up to individual officers to balance open-mindedness with common sense. Local officers have often asked for name lists, and there were in fact two semi-official lists, one drafted in 1865 and the other in 1883 (Lefebvre-Teillard 1990, 137-38). The lack of an official inventory has however not kept some public officers from invoking it when refusing a name: "this name isn't on the list," or "it's not in the book" (Besnard \& Desplanques 1991, 300).

When I visited the central town hall of Lille, the employee in the registry office for births explicitly told me: "You can't choose just any name. It has to be in the book. And not just any book, but an encyclopedia of names like this," and she showed me de Gravelaine's Encyclopédie des prénoms, which lists some 6000 names. The public officers made no mention of saints and calendars-perhaps they could not because of the 1905 law separating the Church and State. Nonetheless, the centrality of saints and calendars to the legal text itself reflects the enduring influence of the Church over naming despite France's anti-clericalism. ${ }^{4}$

When public officers had reservations about a name, they were instructed to ask parents to justify their choice by providing proof of a name's tradition and exact spelling. Though not specified in the General Instructions, appropriate proof included government documents, calendars, naming books, the Koran or the Bible (de Foville 1991, 29-30).

A Baptist acquaintance in Lille, for example, told me that a friend had recently come over to his house looking for a Bible because the town hall would not accept Priscille, the name they had chosen. It was accepted once they showed it to occur in the Bible. Priscilla, which is 


\section{Names 45.3 (September 1997)}

listed in naming books, began being adopted in 1979, but Priscille was a more recent variation (Besnard \& Desplanques 1991, 242; de Foville 1991, 525-26).

Similarly, a university student explained that her family had had to provide proof that the spelling variation Léticia existed (as opposed to the more common French, Laetitia). She said they found the name in a Brazilian dictionary and were only then allowed to use it.

In the early sixties, Sandrine, a derivative of Alexandrine that was to become a very common name for babies born in the late 1960s and early 1970s, was refused as an aberrant spelling of the saint's name, Cendrine. One of the people I talked to, Sandrine, explained that her father was able to register her name in Paris only by going to a second town hall. (It is unclear how he was able to choose another as normally one is required to register the birth in the administrative district where the child is born.) Sandrine has since been assigned the feast day of April 2 on the French saints' names calendar (Besnard \& Desplanques 1991, 246).

At about the same time, as reported by a different observer, a Sandrine was born in Charlesville. Her parents had wanted to call her Cendrine, but they were refused because of the spelling of the name. This is just one example of how this naming law, though "centralized," has been applied in different and indeed even contradictory ways.

It is not clear why these particular local officials insisted that one spelling be substituted for the other, but there are at least two possible explanations. Perhaps unusual spellings make it appear that the parents do not know how to spell the name correctly, and thus the child is stigmatized as belonging to an uneducated family. This is analogous in the United States to African-American names such as Cynequa (pronounced "Seneca") and Meschelle that suggest that parents have heard a name they do not know how to spell in the standard way. In both cases, it is wrong to assume illiteracy or an error, for these creative spellings may reflect the parents' search for a unique name or the value placed on invented names in a particular culture (Black 1996, 109).

In the case of Sandrine/Cendrine related words such as Cendrillon 'Cinderella', cendres 'ashes' and sandre 'pikeperch' may play a role. The conflicting decisions of the two civil servants described above may reflect their differing views and knowledge of the etymology of names 
along with the importance they attach to associating or dissociating a name with related words.

The 1803 law did not take into account feminine derivations, with the result that many common names, such as Henriette and Juliette, were technically illegal, though accepted by some town halls. In the early twentieth century, these derivations were particularly fashionable as seen in the widespread choice of names such as Yvette, Huguette, Jacqueline and Simone. Another more limited source of girls' names was that of flowers. Rose and Rosette were readily accepted, but more questionable were Violette, Violane, Muguette and Primevère. About flower names in the 1930s, Dauzat reports, "One office would say yes, another, no" $(1939,60)$.

Although the modified General Instructions answered some of the questions left open by the 1803 law, interpretation was varied. In some places the General Instructions contradicted the original law, but in others it was referred to as precedent and used as a "defense" by officers when refusing names they deemed harmful to children. For instance, the patronymics of saints, such as Chantal (sainte JeanneFrançoise), Gonzague (saint Louis de), and Xavier (saint François) were deemed acceptable in one section of the text, but in another family names were forbidden. The same equivocation applies to non-calendar names that exist as common nouns, such as the plant names, Olive and Violette (Journal officiel 1990, 138).

Throughout this period the Catholic Church remained an authority (the family names of saints constitute the one exception to the prohibition against using family names as given names). It is significant that well after the official separation of Church and State, the patronymic of Jean-Marie Vianney, a nineteenth century priest canonized in 1925 as the patron of all priests, has become an acceptable given name with a feast day of August 4 (Besnard \& Desplanques 1991, 73).

An American living in France in the late 1980s was questioned for having chosen for her son's middle name her own last name, Caldwell. French people would remark to her, "but Caldwell isn't a given name." A linguist at the University of Lille, when pressed about what he found so very odd about American names finally said, "well, they use last names as given names." 


\section{Names 45.3 (September 1997)}

It would seem from these comments that the distinction between French family names and given names was absolutely clear, but this is not the case. Given the history of how personal names developed, it is not surprising that the most prevalent family name in France, Martin, is also a given name. Ambiguous names such as Thomas, Pierre, Etienne, Bernard and Charles abound. Nicknames which originally denoted filiation developed into permanent family names (de Foville 1991, 35; Dupas 1988, 37). This transition from nickname, that is, the name actually used in day-to-day communication, to official family name was integral to the development of personal naming in France. The reverse process, however, of French family names becoming given names has never been the practice.

For nearly two centuries, the notion of "calendar" was used in judging appropriate names, even though the 1803 law did not clarify which calendars were acceptable. A brief history of saints' name calendars and the Revolutionary calendar is instructive.

Prior to 1634 , sainthood had been conferred without precise rules, but in that year conditions for access to sainthood were codified to include a major inquest into the orthodoxy of candidates' faith, the manner in which they practiced their virtue, and an assessment of whether or not miracles resulted from their intercession. The official Catholic list has over 10,000 saints, with names such as Jean and Pierre being shared by several saints. There are also archaic names such as Aubièrge, Babine and Rufin.

In order to include national saints, the Catholic Church created a universal calendar for use in churches all over the world. Although there are relatively few names because of the numerous days left blank (e.g., all of Lent), it includes saints from all countries and centuries (even Japanese and Ugandan martyrs). Calendars of national saints' names draw from the Roman calendar, but add saints unique to a country and usually do not leave any days empty. In France, the Church has approved the official post office calendar, which has one saint per day except holidays where there is none. In addition, French clergy have made a list of 600 common given names, linking each one with a patron saint. Dictionaries of French given names refer to this basic list (de Foville 1991, 41-43).

To complicate the picture, during the Revolution, a secular Republican calendar was adopted in which saints' names were replaced by farm animals, products, plants and instruments. Fabre d'Eglantine, 
in his Report to the National Convention as spokesperson for the committee that had drafted the new calendar, explained that France could no longer use the saints' name calendar that had been the instrument of deception and domination by kings and the Church (Calendrier des républicains français 1793, 1-21). What was needed was a new calendar that was symmetrical and more exact in its calculations, but which above all provided the people with new images.

Fabre d'Eglantine points out that the people could not see, let alone know those so-called saints of the Church calendar. He continued that by focusing on the dead, priests had attempted to keep the people dependent on the Church by teaching them not to value earthly riches. In order to make the saints more relevant to the people, the Church had attributed to them direct influence over certain aspects of everyday life. St. John, for example, was the distributor of the harvest, and St. Mark the protector of the vine. The authors of the revolutionary calendar eliminated the intermediary of saints and dedicated their calendar directly to nature and the rural economy. They chose names for the months and days whose meaning and prosody were intended to enable people to remember them; they replaced the fanciful images of saints with what they deemed intelligible and useful signs (Calendrier des républicains français 1793, 14; Le Calendrier républicain 1989).

Although the 1803 prénom law was written while the Republican Calendar was still in effect, it was already being attacked as the "calendar of the tyrants." There was a gradual return to the liturgical calendar, a return that was necessary for Napoleon in his effort to make the Catholic Church the State church. The Church calendar was thus officially reintroduced January 1, 1806 (Le Calendrier républicain 1989, $15-16,87,90)$.

When the 1803 law was opened up to names from foreign calendars, the principal sources of new names in late twentieth century France, namely Anglophone countries, are still not included as they do not generally use saints' names calendars. Furthermore, if one were to strictly apply the calendar criterion, many legally acceptable names would be far more absurd, and thus susceptible to ridicule, than names the law would refuse. Artichaud 'artichoke' for example, from the Revolutionary calendar, is stranger than the borrowed Vanessa (disputed in the early 1970s and now common), and Fridolin (now a pejorative term for Germans) is more undesirable than the nature terms, Alizée 'tradewind' and Océane 'ocean' (Besnard \& Desplanques 1991, 300-01). 


\section{Names 45.3 (September 1997)}

Clearly, therefore, the notion of calendars did not provide an adequate, up-to-date source of names used in France or deemed acceptable by French law, either inclusively or exclusively.

Isabelle Bourgeois has pointed out that the law had become more flexible; names such as Makno, the name of a Ukrainian anarchist who died in 1935, had been accepted, and this is hardly "ancient history," (1991). Like the officers at the Lille town hall, Bourgeois noted that the primary purpose of the law had been to keep parents from choosing ridiculous names, but even that was not clearly defined. "The courts have rejected Prune, Jade (more recently allowed) and Toulouse (even though inspired by the painter Toulouse Lautrec), but they have accepted Bergamote '(bergamot) orange', Serpette 'pruning hook' and even Arrosoir 'watering can'" (Bourgeois 1991, 80). ${ }^{5}$

With the 1987 opening up of the inventory to include established foreign names, the calendar criterion disappeared, and thus the core of the 1803 law appeared to have been abandoned. Despite its presence in every home, the saints' names calendar does not seem to play a major role today, other than among bakers and florists who sell bouquets and cakes intended as gifts for those whose saint day it is.

As recently as 1984 , however, the letter of the law was invoked to refuse the registration of children. In February 1982, in a small town in central France, a daughter was born to Jean-Pierre and Marie-Hélène, who wanted to call her Manhattan. This name was refused by the public officer, and the state attorney (procureur) in turn asked the court to give the girl a name. The court chose Marie Hélène Pierrette, based on the parents' names. The parents appealed the decision to the Court of Poitiers, explaining that Manhattan was the title of a hit-parade song in 1973, the year they married, that they liked American culture very much, and that Manhattan had already been admitted in other communes. In April 1983, the court refused their appeal and confirmed the prior judgment.

The parents then went to the higher court of appeal, claiming that parents could choose any name as long as it was not judged ridiculous and pointing out that previous courts had in no way proven the name ridiculous, and that there was therefore no legal basis for denying this name. The Court refused the appeal by referring to the unabridged 1803 law stating that names must come from calendars and people known in 
history. Manhattan did not have an established tradition as a name in any culture, and was thus definitively rejected in July 1984 (de Foville 1991, 31-32). ${ }^{6}$

This case brings up another issue in applying the naming law: was a name to be examined case by case or did precedence apply? The answer apparently is both. Christine Lecas, a public officer, describes the angry reaction of some French parents when a name they choose is not accepted because it lacks a tradition of usage: "Listen, shall I renounce my baptism and call myself Ben Mohamed? That way you'll accept any name." Lecas responds by saying that each name is accepted or rejected based on the specific identity of each family (1990, 205-06).

The General Instructions clarify this point in two ways: (a) names can be justified by one's family tradition, and (b) when a departmental court accepts a name the public officer has questioned, the officer does not have the right to invoke decisions made by courts in other districts (Journal officiel 1990, 137, 139).

Precedence, nonetheless, plays an important role. The inconsistent application of the law throughout France and over the years is a source of frustration, but it appears that after sufficient attempts and after a variable period of time, many names have become accepted (Besnard \& Desplanques 1991, 301). Public officers have been hesitant both to refuse names as well as to set a precedent, and have thus been more inclined to admit questionable names if hyphenated with a traditional name (e.g., Marie-Normandie) or placed in second position (e.g., Vincent Arie) (de Foville 1991, 30).

With the exception of compound names, the French tend to use only their first prénom in daily life, and it is to this name that the 1803 law has been most stringently applied. Public officers thus frequently ask parents to change the order of given names or to add a "first" name. I discovered a case from the 1970s where a family in Lille was required to place the Irish name they had chosen for their son in second position, even though the father was of Irish descent. For birth certificate purposes, the parents ended up naming their son Guillaume Liam, or translated from French and Irish respectively, 'William William'. He uses Liam in daily life.

Rubellin-Devichi points out that courts applying name-change laws have been much more willing to change name order than to remove a 
name, out of respect for the parents' original choices (1990, 140-41). When I asked the Lille public officers how names become acceptable, they replied-in direct contradiction to the General Instructions-that a name just had to be accepted by some state attorney anywhere in France. They cited Logan and Sue-Ellen as names that were rejected at first and then subsequently accepted. So despite the finer tuning of the law, there still existed areas where individual officers could implement their personal opinions, be they conservative or open-minded.

Furthermore, the law as it stood was unable to prohibit names that were potentially harmful or ridiculous because of their association with a last name. For instance, one child from the Lyon area was named Aude Vaissel 'dishwater'. Félicité Lanuit 'happiness at night', was later able to change her name without difficulty. Of course subsequent punning with married names cannot be predicted or controlled, but such names can be officially changed. André Lapierre (personal communication) points out that records of name changes in the Journal officiel show that the courts regularly authorize changes from those names having potentially infelicitous meanings.

Many people I talked to are conscious of the word plays that can occur with first and last names, and they often mention the fictitious twins, Alex Terrieur and Alain Terrieur, 'on the outside' and 'on the inside'. In fact, there is a series of jokes comparable to "nock, knock" jokes in English whose punch lines all involve puns: "Monsieur et Madame Untel ont une fille/un fils. Comment s'appelle-t-elle/il?" For example, "M. et Mme Tare ont une fille. Comment s'appelle-t-elle?" "Maggy." (Maggy Tare = ma guitare 'my guitar'.) This kind of joke is highly productive in French because of the open syllable structure and the abundance of homophones.

Humor of another kind can also occur because French last names often denote human characteristics. A colleague at the University of Lille laughingly told me that his brother nearly named his son Alexandre, Alexandre Lecourt 'Alexander the Short' as opposed to Alexandre Le Grand 'Alexander the Great'.

A new naming law was adopted in 1993. It was included in a set of laws inspired by the 1989 International Convention on Children's Rights. These laws were designed to more adequately protect the rights of children by updating the Napoleonic Code to reflect modern France where $33 \%$ of children are born to unmarried parents, and $50 \%$ do not 
live with both biological parents. ${ }^{7}$ Children's names are generally chosen by their parents. In the event that the parents are not known, the public officer bestows several given names, the last of which serves as the family name. The officer immediately writes these names on the birth certificate. Any one of them may serve as the actual name by which the child is called. This manner of naming foundlings was in practice even prior to the revolution, and the absence of true family names underscores foundlings' lack of filial ties (Journal officiel 1990, 139; Lefebvre-Teillard 1990, 69-70; Loquin 1992, 33).

When, however, one or more of the names, alone or associated with another name (including the family name) seems contrary to the interest of the child or to the rights of another party, the public officer must without delay notify the state attorney, who may in turn appeal to the judge of family affairs. A March 3, 1993 circular clarifies what is meant by names contrary to the child's best interest:

Les prénoms "ayant une apparence ou une consonance ridicule, péjorative ou grossière, ceux difficiles à porter en raison de leur complexité ou de la référence à un personnage déconsidéré dans l'histoire" ou encore les vocables "de pure fantaisie" (quoted in Besnard \& Desplanques 1993, 44).

"Given names "that look or sound ridiculous, belittling, or vulgar; names that are awkward to bear because they are complex or relate to a historical figure of ill repute," or else labels "that are purely fanciful."

If the judge decides that the name is harmful to the child or another party, he or she will order it removed from the register, and if the parents do not choose a name that meets the criteria specified by the law, it is the judge who names the child (Chombeau 1992; Giraudo 1991; Journal officiel 1993, 495). ${ }^{8}$

This law has in effect legalized much of what had been the practice throughout the twentieth century. The main difference between the new law and recent applications of the 1803 legislation is that questionable names are to be recorded immediately in the public registers; any legal action takes place after the birth certificate is drafted and cannot, thus, delay the registration process.

The varied interpretations and inconsistent applications of the 1803 naming law manifested the need for revised legislation on naming in France. As the generally accepted role of such a law evolved throughout 


\section{Names 45.3 (September 1997)}

the past century, public officers and courts have themselves acted in individualistic and seemingly whimsical ways to ensure that parents not do the same in choosing a name for their child.

Despite the prevalence of stories about names which officials have refused, de Foville has put forward the provocative statistic that $90 \%$ of names currently given to children already existed in their same form 400 years ago $(1991,19)$. If this assessment is sound, there has been a remarkable conformity over four centuries. Why then all the discussion of aberrant names? Why were my informants so ready to mention "harmful" or "ridiculous" names, if creative departures do not often occur? There are several possibilities.

Unusual names stand out as exceptions in part because the State succeeds in repressing many unusual names, and more importantly because it is formative in the way people view names and in their naming practices. Also, and in spite of attempts by some philosophers of language such as Mill (1941) and Searle (1967) to show that names are arbitrary signs serving merely to designate, the fact that both the French State and individuals are concerned about the effects of unusual names suggests that given names do more than refer. They do bear meaning and they serve to create one's personal identity.

De Foville's statistic reflects the fact that record keeping itself is done by government agencies and that statistical analyses draw almost exclusively on registered names, not on names actually used in everyday life. Given that each individual is called by multiple names, names unique to contexts and time periods, a study including all names that are used would be considerably larger in scope. And it would no doubt reveal an even more complex relationship between naming and social structures.

Burguière (1990), in a historical discussion of French baptismal names and how they differed from names actually used, says that the creative nature of naming inheres in freeing oneself from institutionalized forms (26). Similarly, Segalen (1980) in "Le nom caché" 'The hidden name' remarks upon the gap between one's official identity-which belongs to the (French) State-and one's identity within the family or village:

Le prénom et le nom de l'état civil, eux, ne disent rien sur un individu: ils nomment, mais ne qualifient ni ne jugent. Tel le costume de fête, l'identité 
officielle constitue l'habit que l'on revêt dans les occasions exceptionnelles, pour aller à la noce ou chez le notaire. C'est le temps de l'apparat et de la parade. Au contraire, l'identité officieuse est celle du quotidien. Elle est attribuée, modifiée et manipulée par la communauté locale. Elle révèle les aspects multiples de la personnalité. Dans cette région de forte homonymie, elle désigne chacun comme un être unique.

"Official state family and given names don't tell you anything about an individual: they name, but they don't characterize or judge. Like one's Sunday best, official identity is the apparel you don for special occasions, for going to weddings or to the lawyer's. For pomp and circumstance. In contrast, one's unofficial identity has to do with everyday life. It is given, modified and manipulated by the local community. It reveals multiple aspects of a personality. In this region where so many names are shared, it designates each person as a unique individual." (76)

Names serve many different and sometimes contradictory functions. They are at the same time public and private, and they both index the history of one's family and cultural identity as well as express expectations for a newborn's future individuality and well-being.

Throughout the evolution of the 1803 naming law (requiring a calendar name) into the 1993 law (prohibiting names deemed potentially harmful to the bearer or to another party), there were repeated instances of conflict between individuals and the State as well as numerous inconsistencies in applying the law. Such inconsistencies are not surprising given that the implementation of the naming law lay ultimately with local officials who apparently had no standardized training or common instructional background. Furthermore, the law specifically prohibited accepting questionable names based on precedent in one or another region of France.

The conflict between individual namers and the State arises from the paradoxical situation that the names of people belong to the State and yet are intensely personal. The State has complete jurisdiction over the admissibility of names and over name changes. Loquin points out that "Individuals are no more the owners of their name, than they are the possessors of their social security number" $(1992,34)$. At the same time, however, the law is meant to assure people's rights as citizens of France to choose their children's names and to be protected against misuse of their names.

The situation is further complicated by the fact that both officials and French people in general act according to their own conception of 
what the law is. No one whom I interviewed in Lille-including the town hall officials-had read the actual law. Individuals did not hesitate, however, to tell me their understanding of the law, understandings which varied considerably and were often based on second-hand stories of people who had chosen an unusual name and had fought the official's refusal to record that name on the birth certificate.

The irony remains then that something so intimately tied to one's unique, personal identity as a given name is at the same time subject to an impersonal, complex and seemingly capricious bureaucratic system.

\section{Notes}

This article draws on a larger study I conducted in 1991-1993 in Lille for a doctoral dissertation at Indiana University, "An Ethnographic Study of Given Names in Lille, France." I gratefully acknowledge the contributions of Albert Valdman, Michael Berkvam, Martha B. Kendall and Samuel Rosenberg. In addition I received very helpful suggestions from two anonymous reviewers for Names.

1. The central details of this story were recounted to me by Saskia's mother, a colleague at the University of Lille.

2. Following the Renaissance and its infatuation with names from antiquity and the Reformation with its penchant for biblical names, the Catholic Church determined through the Counter-Reformation to limit the choice of baptismal names. Whereas previously the Church had merely encouraged parents to choose saints' names, in the mid-sixteenth century at the Council of Trent it required people to choose saints' names. The saint's name was intended to motivate the name bearer both to imitate the saint's virtue and to pray for the saint's protection and intercession. The priest was charged with ensuring that the Council's ruling was carried out. So-called "heathen" names were eliminated by the priest who refused to bestow such names at baptism, the name bestowal ceremony (Dupâquier et al. 1984, 1).

3.Translations are mine throughout. An anonymous reviewer, however, suggested numerous ways to capture the French nuances more clearly.

4. The Church's continuing authority over naming, albeit indirect, contributes to the lack of Muslim integration in France; the Catholic and Muslim traditions of naming differ so greatly that it is difficult to find an Arabic name-especially for boys-that does not stand out and thus invite stigmatization within French society. The Church's influence also partially accounts for the fact that created names (such as those popular among African-Americans) are unthinkable to many French people. The role of the Church is, of course, intertwined with the French republican ideal in maintaining rigid naming norms. Peggy, a student at the University of Lille, described how as recently as the 1970s, a priest refused to baptize her as Peggy, so her parents gave her her grandmother's name, Marie, only as a baptismal name.

5. André Lapierre describes the proliferation of ridiculous sounding names during the late nineteenth and early twentieth centuries in French Canada. 
Intellectuals decried the punning of names such as Helvida Labarre 'she emptied the bar' and sought to promote "socially and linguistically acceptable" names (1996, 43 and personal communication).

6. Manhattan may have a Native American tradition. Note, however, that for all of the "questionable" names discussed above, written proof of their "tradition in some culture" has been used, and not just any written proof, but rather a document such as a dictionary, religious work, or legal family records, all of which reflect a highly codified language and culture.

7. There are three main parts to this law: (a) the granting of greater liberty to parents in choosing a name, (b) the revision of filiation rights, and (c) the institution of a judge responsible for family matters. This law also simplifies the procedure for legally changing one's name and makes it more possible for minors to have a hearing in court.

8. Besnard \& Desplanques (1993) cite Babar as having been deleted in September 1993 from the état civil of a girl whose parents had chosen it as her third prénom because it was an "animal" name (45).

\section{References}

Adler, Max K. 1978. Naming and Addressing: A Sociolinguistic Study. Hamburg: Helmut Buske.

Besnard, Philippe, and Guy Desplanques. 1991. Un Prénom pour toujours: La cote des prénoms. Paris: Balland. . 1993. La cote des prénoms en 1994. Paris: Balland.

Black, Kerrigan. 1996. "Afro-American Personal Naming Tradition." Names 44: 105-25.

Bourgeois, Isabelle. 1991. "Choisir un prénom: passionnant...mais pas facile!” Parents November: 79-82.

Burguière, André. 1980. "Un Nom pour soi: Le choix du nom de baptême en France sous l'Ancien Régime (XVIe-XVIIIe siècles)." L'Homme 20: 25-42.

Calendrier des républicains français. 1793. Paris: Imprimeurs Réfugiés liégeois.

Chombeau, C. 1992. "Les Pères d'enfants naturels pourraient bénéficier automatiquement de l'autorité parentale." Le Monde 29 April: 10.

Dauzat, Albert. 1939. Les Noms des personnes: origine et évolution. 4th ed. Paris: Delagrave.

de Foville, Jean-Marc. 1991. Les 1000 prénoms pour vos enfants. Paris: Hachette. 


\section{Names 45.3 (September 1997)}

de Gravelaine, Frédérique. 1989. Encyclopédie des prénoms. Paris: Robert Lafont.

Dupâquier, J., A. Bideau, \& M.-E. Ducreux, Eds. 1984. Le Prénom: mode et histoire: Les entretiens de Mahler 1980. Paris: L'Ecole des Hautes Etudes en Sciences Sociales.

Dupas, Georges. 1988. Les Noms de personnes en Flandre-Artois du XIIIe siècle à nos jours: Essai d'anthroponymie régionale et comparée. Editions des Beffrois.

Giraudo, A. 1991. "Les parents pourraient choisir plus librement les prénoms de leurs enfants." Le Monde 22/23 December: 1 \& 8.

Journal officiel de la République française. 1990. Instruction générale relative à l'état civil du 21 septembre 1955.

. 1993. Loi no. 93-22 du 8 janvier 1993 modifiant le code civil relative à l'état civil. January 9: 495-99.

Lapierre, André. 1996. "One Hundred Years of Onomastic Writing in French Canada." Onomastica Canadiana 78: 41-51.

Le Calendrier républicain: de sa création à sa disparition suivi d'une concordance avec le calendrier grégorien. 1989. Paris: Service des Calculs et de Mécanique Céleste du Bureau des Longitudes Unité Associée du CNRS.

Lecas, Christine. 1990. "Législation et illustrations." Le Nom et la nomination: Source, sens et pourvoir. Ed. J. Clerget. Toulouse: Erès, 201-07.

Lefebvre-Teillard, Anne. 1990. Le Nom: Droit et histoire. Vendôme: Presses Universitaires de France (Léviathan).

Loquin, Eric. 1992. "Le Nom et le droit français." Dictionnaire historique des noms de famille romans. Actes du Collque IV (Dijon 1990), Patronymica Romanica 6: 31-38. Tübingen: Niemeyer.

Mill, John Stuart. 1941. A System of Logic: Ratiocinative and Inductive. 8th ed. London: Longmans, Green and Co.

Rubellin-Devichi, Jacqueline. 1990. "Le Droit, le nom et la nomination." Le Nom et la nomination: Source, sens et pourvoir. Ed. J. Clerget. Toulouse: Erès, 137-47.

Searle, John R. 1967. "Proper Names and Descriptions." The Encyclopedia of Philosophy. Ed. P. Edwards. New York: Macmillan and London: Collier Macmillan, 487-91.

Segalen, Martine. 1980. "Le Nom caché: la dénomination dans le pays bigouden sud." L'Homme 20: 63-76. 